\title{
Türkiye'de Afet Yönetimi ve İş Sağlığı Güvenliği
}

\author{
Şakir ŞAHİN1, İbrahim ÜÇGÜL²
}

\section{Özet}

$\mathrm{Bu}$ çalışmada, afet yönetimi ile iş sağlı̆̆ı ve güvenliği ele alınmış konu hem yasal hem de uygulama açısından değerlendirilmiştir. Afet yönetimi afet öncesi, sırası ve sonrası planlama şeklinde ele alınabildiği gibi, önleme ve zarar azaltma, afetlere karşı hazırlık, kurtarma ve ilk yardım, iyileștirme ile yeniden inșa evrelerinden olușan bir planlama sürecidir. Bu bağlamda 2013 yılında yürürlüğe giren Afet ve Acil Durum Müdahale Yönetmeliği'nin daha çok kriz yönetimi evreleri olan müdahale ve ilk yardım ile yeniden inşa aşamalarını düzenlediği görülmektedir. Ancak afet yönetiminin birinci evresi olan risk yönetiminin risk değerlendirme ve zarar azaltma ile hazırlı aşamaları 6331 sayılı İş Sağlığı ve Güvenliği Kanunun ilgili yönetmeliklerince düzenlemektedir. Afet yönetiminin uygulanması için bu iki yasal düzenlemenin birlikte uygulanması gerekmektedir. Buradan çıkan sonuç, sosyal ve çalışma hayatının güvenli bir șekilde devamı, ülke kalkınmasının sürdürülmesi ve iş sağlığı ve güvenliğinin sağlanması ancak iyi bir afet yönetim planının uygulanması ile mümkündür. $\mathrm{Bu}$ çalışmada afet yönetimi ile temel kavramlar ele alınmış, deprem tehlike durumu, afet türleri, afet yönetim sisteminin aşamaları incelenmiş ve uygulamada karşılaşılacak sorunlar ortaya konularak Türkiye'de bütünleşik afet planının oluşturulması ve uygulanabilirliği ortaya konulmuştur.

Anahtar Kelimeler: Afet Yönetimi, İş Sağlığı ve Güvenliği, Kriz, Risk

\section{The Disaster Management And Occupatinal Helath Safety In Turkey}

\begin{abstract}
${ }^{1}$ Prof. Dr., Jeofizik Mühendisliği Bölümü, Mühendislik Fakültesi, SDÜ, Isparta

İlgili yazar / Corresponding author: sakirsahin@sdu.edu.tr

${ }^{2}$ Prof. Dr., Tekstil Mühendisliği Bölümü, Mühendislik Fakültesi, SDÜ, Isparta
\end{abstract}

In this study, the disaster management and the occupational health safety have been investigated and the issue has been evaluated both legally and in terms of application. Disaster management can be considered as pre-disaster, order, and post-disaster planning as well as prevention and damage reduction, disaster preparedness, rescue and first aid, improvement and reconstruction. In this context, it is seen that Regulation of Disaster and Emergency Response operating form 2013 regulates the stages of crisis management, intervention and first aid and reconstruction. However, risk assessment, risk reduction and mitigation and preparation stages of the first stage of disaster management are regulated by the relevant regulations of the Occupational Health and Safety given law No 6331. For the application of disaster management, these two legal regulations must be implemented together. The result is that a safe life of the working life and the maintaining the country's development is only possible within effective disaster plan. In this study, basic concepts of disaster management were explained, the features of earthquake hazard, disaster types stages of the disaster management system were examined and It has been 
Türkiye'de Afet Yönetimi Ve İs Sağlı̆̆ı̆ Güvenliğ̈i

introduced the feasibility of establishing and integrated disaster plans in Turkey with evaluated the problems in applications.

Keywords: Disaster Management, Occupational Health And Safety, Crisis, Risk

\section{GíRiş}

İnsanlık var oluşundan bu yana doğayı anlamaya çalışmaktadır. Pozitif bilimin de temelini oluşturan bu anlayış ile insan doğa olayları ile mücadele etme çabası içerisindedir. Ancak ne var ki üzerinde yaşadığımız dünyanın kendine özgü yıkıcı olayları can ve mal kaybına neden olabilmektedir. Doğa kaynaklı ve teknolojiye bağlı insan hayatını olumsuz etkileyen yıkıcı olaylara afet denilmektedir. Diğer taraftan herhangi bir doğa olayının afet olarak tanımlanması için, ölüm ve yaralanma ile belli bir maddi değerin üzerinde kaybın olması gerekir.

Afetler genellikle aniden meydana gelen, ekonomik ve sosyal kayılara neden olan olaylardır (Varol ve Gültekin, 2016a). Bunlar hasara neden olan deprem, çı̆̆, heyelan, kaya düşmesi, volkan patlaması, tayfun, sel gibi olaylar aniden oluştuğundan afet şeklinde tanımlanmaktadır. Diğer taraftan kuraklık, çevre kirlenmesi, orman tahribatı, erozyon, atmosferik olaylar, deniz suyu yükselmesi, küresel ısınma gibi olaylar zamanla geliştiği için tehlike olarak görülmekte ve afet şeklinde nitelendirilememektedir. Ancak küresel iklim değişikliği ile birlikte bu doğa olayları can ve mal kayıplarına neden olmakta, dolayısıyla afet olarak tanımladığımız olaylara dönüşmektedir. Küresel iklim değişikliğinin neden olduğu afetler günümüzde küresel göç faktörünün de temel nedenlerinden biri haline gelmiştir (Varol ve Gültekin, 2016b).

Afetleri yavaş gelişen ve hızlı gelişen afetler şeklinden sınıflandırmak mümkündür. Yaban hayatı ve ekolojik dengenin bozulması, küresel iklim değişikliğine yol açan sera gazı etkisi, kuraklık, doğal haliyle bırakılması gereken kıyı şeritlerinde yüksek yapıların inşa edilmesi gibi uzun yıllar sonra etkisini gördügümüz afetler meydana gelmektedir. Yavaş gelişen afet olarak tanımlan bu olayların yanı sıra deprem, tsunami, heyelan, çığ gibi ani ve hızlı gelişen afetler meydana gelmektedir (Varol ve Gültekin, 2016a). Tüm bu afetlerin olumsuz etkilerinin en aza indirilmesi çok disiplinli afet risk yönetimi ile mümkün olabilecektir (Varol ve Kaya, 2018).

Olayın büyüklüğü, nüfus yoğunluğu ve yerleşim alanına olan uzaklık, az gelişmişlik, bununla birlikte nüfus artış hızı, afet riskinin yüksek olduğu alanlarda hızlı ve kontrolsüz yapılaşma, teknik, malzeme ve işçilik yersizliği, güvenlikten uzak ve niteliksiz yapı, yapılan kontrol edilmemesi, sanayileşme, ormanların tahribi, bilgisizlik ve eğitim eksikliği ve toplumun duyarsızlığı afetin şiddetini artırmaktadır (Wamsler, 2007). Bu hususların özellikle olayın büyüklügü ve nüfusun yoğunlaştığı alanlara uzaklığı dışında kalan unsurlar, insan faaliyetlerine bağlı olarak gelişir. Sonuç olarak afetlerin etkisi, çoğunlukla insan kaynaklı faaliyetlerin doğru veya yanlış yönde gelişmesine göre şekillenmektedir (Ergünay, 1996).

1999 yılında meydana gelen Gölcük ve Düzce Depremleri, ülkemizde çağdaş ve bütünleşik bir afet yönetim planının oluşturulmasının gerekliliğini ortay koymuştur (Ertürkmen, 2006). Buna yönelik yapılan yasal düzenlemeler ve oluşturulan kurumlar özellikle kriz yönetiminde başarı sağlanmasında bir bilincin olușmasına vesile olmuştur. 23 Ekim 2011 Van Depremi ise bu alanda bir miladın adı haline gelmiştir. 2009 yılında Afet ve Acil Durum Yönetimi Başkanlığı'nın (AFAD) kurulması ve.12.2012 tarihinde yürürlüğe giren 6306 sayılı Kentsel Dönüşüm Kanunubu bilincin ürünüdür.

Geleneksel modelde afet yönetimi; afetin can ve mal kaybına neden olmaması veya kaybın en aza indirilmesinde afet öncesi ve sonrasında alınacak önlemlerin bütünüdür (Özmen, 2013; Disaster Terminology, 2005). Bu model, sakınım, hazırlı, müdahale ve iyileștirme safhalarından oluşmaktadır (Balamir, 2002; Yücel, 2009; Özmen, 2013). Türkiye’de afet yönetimi 1999 Gölcük 
Afet ve Risk Dergisi Cilt: 2 Sayı: 1, 2019 (43-63)

Şakir ŞAHIN, İbrahim ÜÇGÜL depremi öncesinde daha çok, afet sonrasında gıda ve giyecek yardımları, sağlık hizmetleri ve afetzedelerin barınma ihtiyaçlarının karşılanması şeklinde yürütülmüştür (Tercan 2018). Günümüzde uygulanan afet yönetim sisteminde öncelik kriz yönetiminden risk yönetimine verilmektedir (Erkan, 2010).

Ertürkmen (2006), afet ile ilgili günümüzde ciddi manada kavram kargaşasının olduğunu ileri sürmektedir. Örneğin, acil durumla ilgili, ani olarak ortaya çıkan sıkıntılı durum, yardım ve müdahale yapılması gereken durum, öngörülmeyen veya beklenmeyen olaylar biçiminde farklı ifadeler kullanılmaktadır. Bunların hangisi veya hepsi mi doğru? Aslında buradaki acil kavramı öngörülemeyen ve beklenmeyen salgın hastalık, yangınlar, trafik kazaları, endüstriyel kazalar, terörist saldırılar gibi olayları ifade etmektedir.

Ergünay (1999),afetin doğal olabildiği gibi teknolojik ve insan eliyle de meydana geldiğini ileri sürmüştür. Afet olarak deprem ve volkan patlaması yerin içyapısından, çı̆̆, heyelan, kaya düşmesi, firtına, kasırga, sel ise atmosferik değişimlerden kaynaklanmaktadır. Bununla birlikte orman yangınları, salgın hastalıklar ve savaş gibi insan hayatını etkileyen afetler de insan kaynaklıdır. Eren (1998) afeti, "büyük felaket, bela, yıkım" olarak tanımlanmaktadır Afet insanların sosyoekonomik, sosyo-psikolojik durumlarını etkileyen bir olaydır. Gelișen teknoloji ve buna bağlı sanayileşmenin ortaya çıkardığı küresel iklim değişikliği ile birlikte insanlığın karşı karşıya kaldığı afet sayısı gün geçtikçe artmaktadır.

Afetler deprem, kuş gribi, SARS, çı̆̆, fırtına, sel, yangın, tehlikeli maddeler, gemi ve uçak kazası, terör gibi her zaman ve her yerde değişik şekillerde ortaya çıkmaktadır. Afetlerin gelişmesi bazen günler veya haftalar sürerken, bazen de aniden gelişimi söz konusudur. Can ve mal kaybının en aza indirilmesinde modern ve bütünleşik afet planının önemli olduğu belirtilmiştir (Kadıoğlu, 2008).

Eren'e (1998) göre kriz çoğunlukla afet ile eş anlamlı olarak kullanılmaktadır. Aslınca bir olay sonrası oluşan afet kriz olarak tanımlanmaktadır. Ülkemizde uygulama bu yöndedir. Kriz kavramı, toplumsal, kurumsal veya kişisel olarak yaşanan olumsuz dönem biçiminde açlklanabilir.

$\mathrm{Bu}$ çalışma ile ülkemizde afet yönetiminin etraflıca ele alınması, bu bağlamda eksik olan risk yönetimi konusunu içerecek şekilde Afet Yönetiminin İş Sağlı̆̆ı ve Güvenliği (İSG) ve Afet ve Acil Durum Yönetimi açısından irdelenmesi amaçlanmıştır. Mevcut ve ideal durum çalışma hayatı açısından irdelenerek İSG yönünden önemi ortaya konulmuştur.

\section{TEMEL KAVRAMLAR}

\subsection{Risk Analizi}

Belli bir zaman ve mekânda bir tehlikenin varlığı ve bu tehlike ile karşı karşıya olan unsurların hasar alma veya kayıp verme olasılığına risk denir. Riski, kısaca bir tehlike veya tehlikelerin olası sonuçları şeklinde tanımlamak mümkündür. Bunlar ölüm, yaralanma, hastalık yangın, patlama, heyelan, salgın hastalık, biyolojik, kimyasal ve nükleer kirlenme, kitlesel göç, ayrıca alt yapının hasar görmesi, hizmetlerin durması veya aksaması, tarım, sanayi üretimin durması şeklinde sayılabilir (Kadıoğlu, 2017).

Görüldügü gibi risk, belli bir tehlikenin, belli bir zaman içerisinde insanlara, yerleşim alanlarına doğaya zarar verme olasılığıdır (Kadıoğlu, 2017). Afetler baz alınarak çoğunlukla risk, "afet riski" şeklinde tanımlanır. Afet riski matematiksel olarak en genel haliyle;

Risk = Tehlike $\times$ (Zarargörebilirlik - Yönetebilirlik) 
Türkiye'de Afet Yönetimi Ve İs Sağlı̆̆ı Güvenliğgi

şeklinde ifade edilebilir (Kadığlu, 2017). Başka bir ifade ile risk, belirli bir tehlikenin, belirli bir zaman süresi içerisinde, maruziyet derecesine bağlı olarak canlılara, yerleşim birimlerine ve doğal çevreye zarar verme olasılığıdır (Şekil 1). Görüleceği üzere, riskin belirlenmesi ve analizi, tehlikenin, zarar görebilirlik düzeyinin ve bunun yönetilebilirlik durumunu ifade eder (AFAD).

Afet riski, tehlike, maruziyet ve savunmasızlığın bir kesişimidir (Şekil 1). Afetin etkilerini azaltmak için tehlikeler tamamen bertaraf edilemeyeceğine göre, toplumun maruziyetini azaltmak ve savunma unsurlarını güçlendirmek gerekir (Kadığlu, 2017).

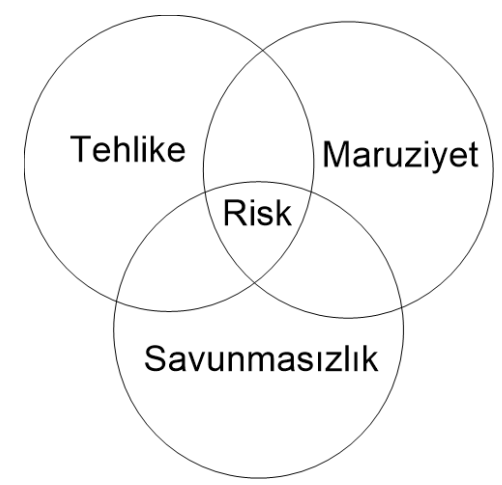

Şekil 1. Afet riski, tehlike, maruziyet ve savunmasızlığın şematik gösterimi (Kadıoğlu, 2017).

\subsection{Afetler}

7269 Sayılı Kanun ve ilgili yönetmeliklere göre, toplumun tamamı veya bir kısmını fiziksel, ekonomik ve sosyal açıdan etkileyen ve kayıplar oluşturan, normal hayatı kesintiye uğratan ve durduran doğal veya teknolojik kaynaklı olaylara afet denir (Tercan, 2011; Ergünay, 2007). Afetlerde can ve mal kaybı söz konusudur. Can ve mal kayıplarının meydana gelmesi, afetin sosyal bir olgu olarak karşımıza çıkmasına neden olur. Afetler, insan toplulukları ve yerleşmeleri üzerinde kayıpların yanında, şaşkınlık, panik, şok, yaralanma, sakatlanma, bulaşıcı ve salgın hastalıklara yol açabilir (Dönertaş, 2006). Kayıp ya da hasar söz konusu olmadı̆̆ı takdirde olay, afet değil doğa olayı olarak adlandırılmaktadır (Ertürkmen, 2006). Toplumun sadece kendi imkânları ile üstesinden gelebilmenin mümkün olmadığı, çevre ve toplum büyük kayıplara yol açan toplumun faaliyetlerini ciddi manada kesintiye uğratan durumlaradır (UNISDR, 2004). Aynı zamanda bir doğal (deprem, volkan patlaması) ya da insan kaynaklı (yangın, teknolojik, terör) tehlike nedeniyle şiddetli hasar, sakatlık, can veya mal kaybının meydana gelmesi durumudur. Afetler Doğal afetler ve Teknolojik Afetler olarak ikiye ayrılır (Ergünay, 1995).

\subsubsection{Doğal Afetler}

Toplum ve tüm canlılar üzerinde kayıplar oluşturan ve sosyal hayatı sekteye uğratan ya da durduran, aynı zamanda can ve mal kaybından dolayı dış yardıma gereksinim duyulan, ekolojik olaylara doğal afet denir (Keçici, 1994). Birleşmiş Milletler Afet Yardım Komisyonu Bürosunca 1974 yılında hazırlanan "Türkiye'de Acil Yardım Teşkilatları" başlıklı raporda Türkiye'de meydana gelen doğal afetler, depremler, toprak kaymaları, kaya düşmeleri, hububat ve orman yangınları, su baskınları, çığ düşmeleri şeklinde sıralanmıştır (Ertürkmen, 2006).

\section{Deprem}

Yer kabuğunda fay düzlemi buyunca kırılmaya bağlı ani yer değiştirme sonucu oluşan dalgaların geçtikleri ortamı ve yer yüzeyini sarsma olayına deprem adı verilir (Erkoç, Bardan ve Hamzaçebi, 2000). Sismotektonik açıdan aktif bir bölgede yer alan Türkiye'de çok sayıda hasar yapıcl deprem meydana gelmiştir. Diğer taraftan Türkiye ile ilgili afet verileri değerlendirildiğinde, olay sayısı en fazla olmamasına rağmen, en fazla can ve mal kaybına sebep 
Afet ve Risk Dergisi Cilt: 2 Sayı: 1, 2019 (43-63)

Şakir ŞAHIN, İbrahim ÜÇGÜL

olan afet türünün depremler olduğu görülmektedir (Gökçe, Demir ve Ozden, 2008). Ortalama 3 yılda bir hasar yapıcı depremin olduğu ülkemizde her gün aletsel olarak kaydedilen çok sayıda deprem oluşmaktadır. Bunların büyük bir kısmı insanlar tarafından hissedilmeyen sadece aletsel olarak kaydedilen depremlerdir. Her yıl ülkemiz topraklarında küçük-büyük ortalama 18.000 deprem meydana gelmektedir (KRDAE). Türkiye'de toplam nüfusunun \%98'i depremden az ya da çok etkilenmektedir. 2018 Türkiye Deprem Yönetmeliği'ne göre yüzölçümünün \% 75'ü tehlikeli /yüksek tehlikeli alan olarak görülmektedir. Deprem tehlikesinin yüksek olduğu alanlarda nüfus yoğunluğu fazladır (Şekil 2). kente yoğun göç nedeniyle her geçen gün daha fazla vatandaşımızın deprem tehlikesi ile karşı karşıya kaldığı söylenebilir. Enerji santrallerinin ve sanayi bölgelerinin büyük bir kısmı bu riskli bölgelerde bulunmaktadır. Bu gün vergi gelirlerinin \% 45'nin İstanbul ve çevresinden toplanıldığı düşünüldügünde olası İstanbul depreminde kayıp durumunun dikkate alınarak hazırlık yapılması gerektiği ortadadır. Zira bu yapılmadığı takdirde, binlerce kişinin hayatını kaybetme riski ile, nasıl 1999 depremi 2001 krizini tetikledi ise bu durum yeni ve daha büyük bir krizi tetiklemesi söz konusu olacaktır.

Kuzy Anadolu Fay Zonu'nun 1999 Gölcük depremi kırığı üzerinde yer alan bir otomobil Fabrikası bu depremde çok büyük hasar almıştır. Hatta fabrikanın yerinin değiştirilmesi gündeme gelmiş, ancak zemin iyileștirilmesi yapılarak fabrikanın yerinde kalması ve deprem gibi doğal afetlere karşı direnci artırılmıștır. Deprem yapısal hasara neden olduğundan hem ilave maliyet oluşturmuş, hem de üretime geçişi geciktirerek ekonomik kaybın katlanmasına sebebiyet vermiștir. Bu da ülke ekonomisine katkının sekteye uğramasına neden olmuștur. Tüm bu anlatımlardan depremin sosyo-ekonomik ve sosyo-psikolojik hayatını etkilemesi açısından ne kadar önemli olduğu ortaya çıkmaktadır.

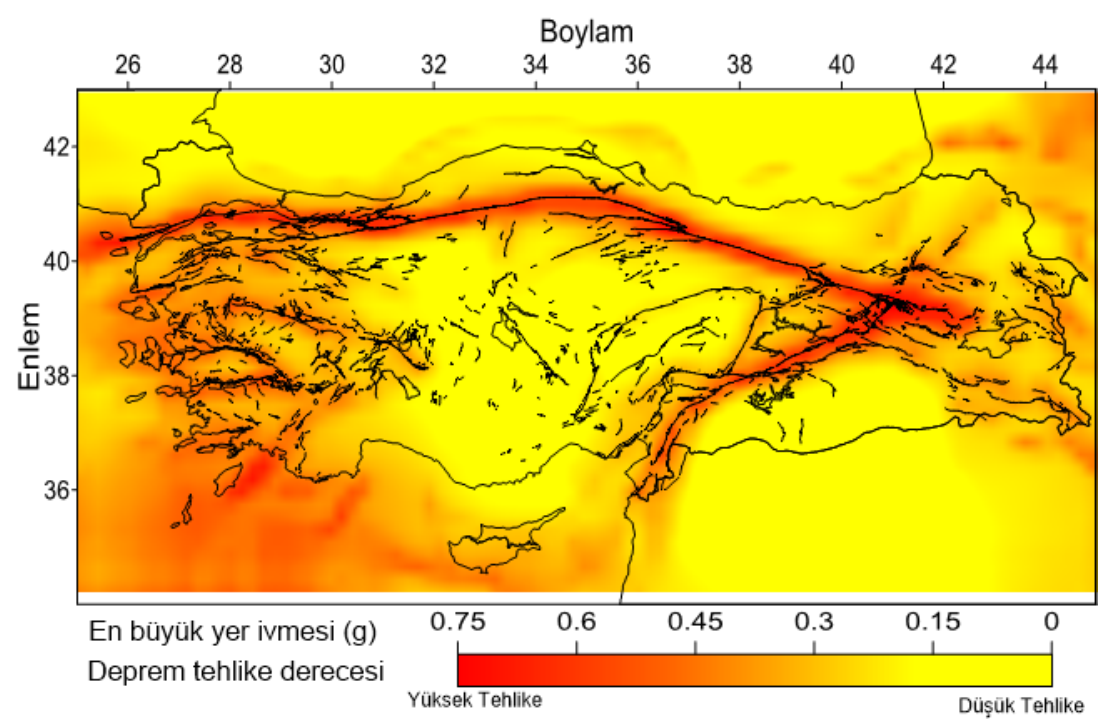

Şekil 2. Türkiye Deprem Tehlike Haritası (AFAD, 2018)

\section{Su Baskını}

Bir akarsu yatağındaki debinin yatağın bulunduğu havzaya normalden fazla yağmur yağması ya da havzadaki karların hızlı bir şekilde erimesinden dolayı suyun yatak çevresinde can ve mal güvenliğini tehdit edecek kadar hızla artmasına su baskını adı verilir. Diğer bir ifade ile doğal afet olan bu olay, bir akarsuyun yatağından taşarak, yatak çevresindeki arazilere, yerleşim birimlerine, altyapıya ve canlılara zarar vererek etkilediği bölgelerde sosyo ekonomik faaliyetlere sekte vuracak şekilde bir akış oluşturması olayı olarak ifade edilmektedir. Bu tanım 
Türkiye'de Afet Yönetimi Ve İs Sağlı̆̆ı Güvenliğgi

içerisine, deniz sahillerinde dalga hareketi kaynaklı sahil baskınları, göl sevilerindeki değişime bağlı olarak gelişen göl taşkınları da girmektedir (Ertürkmen, 2006). Türkiye'de su baskını ve ani taşkınların neden olduğu can ve mal kayıpları meydan gelmiştir. Bu kayıpların azaltılması için 1943 yılında 4373 sayılı "Taşkın Sulara ve Su Baskınlarına Karşı Korunma Kanunu” çıkarılmıştır (TBMM, 1999; Ergünay, 2002; Uzunbıçak, 2005; Tercan, 2008; 2018; Şengün, 2012; Özmen ve Özden, 2013).

Su baskınları, doğal olarak oluşmuş yatağından taşan suyun etkilediği alanda can ve mal kayıplarına neden olabilmektedir. Bu da akarsuyun havzasında hızlı akmasına bağlı olarak yatağın aşınması, hızın azaldığı yerlerde taşkınların olması ve taşınan malzemenin çökelmesi ve bundan dolayı akarsu yatağının değişmesi ile alt ve üst yapı tesislerine zarar vermesi ile hasarlara sebep olmaktadır. Kayıpların ve hasarın oluşmaması veya en aza indirilmesi için dere yataklarının ıslah edilmesi gerekmektedir. Ayrıca kentlerde havza iyileştirmesi, özellikle yağmur suyu kanallarının maksimum yağışa ve su toplama havzalarının büyüklüğüne bağlı olarak projelendirilmesi ve uygulanması gerekmektedir. Özellikle küresel iklim değişikliğine bağlı olarak bu hususlar ülkemiz gündeminde daha sık yer alacaktır. Yerel yönetimler bu alanda strateji geliştirmek durumundadırlar.

Dünyanın birçok yerinde aşırı bölgesel ve yerel yağışlara ya da hızlı kar erimelerine bağlı olarak su baskınları yaşanmaktadır. Sel oluştuğu bölgenin iklim şartlarına, jeoteknik ve topografik özelliklerine bağlı olarak gelişmektedir. Ancak sel veya su baskınının afete dönüşmesi, doğrudan faaliyetlerinin doğaya müdahalesi neticesinde olmaktadır. Özelikle dere yatakları ve akarsu havzalarında plansız ve kontrolsüz yapılaşma dünyanın her tarafında sel felaketinin ana nedenidir.

\section{Çı̆}

Genel olarak kar kütlesinin iç ya da dış etkenlere bağlı olarak yüksekten aşağı doğru akmasına çığ adı verilir. Bu akma bitki örtüsünün olmadığı ya da zayıf olduğu, eğimli vadi yamaçlarında gravitasyonun da etkisiyle gerçekleşmektedir. Çı̆ğ olayı bitki örtüsünün yanında, bölgenin topografyasına, jeomorfolojik ve jeolojik yapısına, meteorolojik durumlara göre gelișir. Başta İsviçre, Avusturya, Fransa (Alpin Ülkeleri) olmak üzere, İtalya, Amerika, Kanada ve bazı Asya Ülkeleri çığ felaketinin sıklıkla yaşandığı ülkelerdir. Bu ülkelerin çoğu gelişmiş olmalarından dolayı çığ, yerleşim yerlerinden daha ziyade kayak merkezleri, bazı iletişim hatları ve ulaşımı etkilemektedir (Gürer ve Yavaş, 1994). Bu ülkelerde yerleşim alanlarında çı̆̆ riski, erken uyarı sistemi, gözlem noktaları, planlı ve önlemli yapılașma ve sürdürülebilir kentleşme ile büyük ölçüde bertaraf edilmektedir. Ancak, kış sporuna ilgi duyan insan sayısının artması ile kayak merkezlerinde oluşan yoğunluk nedeniyle son yıllarda can kayıplarında ciddi bir artış söz konusudur (Ertürkmen, 2006). Diğer taraftan dağcılık faaliyetleri kapsamında çı̆̆ olayına bağlı olarak can ve mal kayıpları yaşanmaktadır.

Ülkemizde, kuzey-kuzeydoğu ve Doğu Anadolu bölgelerinin dağlık alanlara sahip olması coğrafik olarak uygun topografya ve meteorolojik şartlardan dolayı zaman zaman çı̆̆ olayları oluşmaktadır. Son yıllarda ülkemizde de kayak merkezlerinde ve dağcılığın yoğun yapıldığı bölgelerde çı̆̆ afetine bağlı kayıplar yaşanmaktadır. Hatta bu durum yukarıda sayılan bölgelerin yanı sıra oOrta Anadolu'da da görülmektedir. Ülkemiz topraklarının üçte birinden fazlası çı̆̆ afetinin yaşanma riskine sahiptir (Ertürkmen, 2006). Ancak ülkemizde yaşanan çığ afeti az da olsa yerleşim birimlerini etkilemekte, ulaşım ve haberleşme ağlarına zarar vermektedir.

Çığ olayı toplumu sadece sosyo-ekonomik açıdan etkilememekte, çı̆̆ riskine bağlı olarak yerleşim birimlerinin yerleri değiştirilmekte ve nüfusun göç etmesine neden olmaktadır. Ayrıca aşırı kar yağıșının oluşturduğu mağduriyet durumu insanları daha rahat yaşayabilecekleri bölgelere taşınmalarına neden olmaktadır. Ancak terkedilen bu bölgelerin sosyal ve ekonomik açıdan faydalanılabilecek özelliklerinin de göz ardı edilmesine sebep olunmaktadır (Ertürkmen, 2006). Bu tür bölgelerin turizm potansiyeli gün geçtikçe azalmaktadır. 


\section{Firtına}

Rüzgârın $55 \mathrm{~km}$ /saat ve üzere hıza ulaşması ile oluşan hava hareketine fırtına denir (Ertürkmen, 2006). Fırtına başta deniz taşımacılığı olmak üzere, kıyılarda su baskınlarına, iç bölgelerde çatı uçması, ağaç devrilmesi ve baca basması diye tabir edilen soba dumanının mekân içerisine dolması sonucumonoksitkarbon monoksit zehirlenmesine yol açmaktadır. Ayrıca enerji nakil ve iletişim hatlarına zarar vermekte, başta havayolu olmak üzere ulaşımı sekteye uğratmaktadır.

Özellikle okyanus ve denize kıyısı olan ülkelerde basınç ve sıcaklık farklarına bağlı olarak cephesel fırtınalar görülmektedir. Deniz suyu sıcaklığının yüksek olduğu bölgelerde, okyanus suyunun ve atmosferik olaylar ile meydana gelen tropikal firtına, kasırga, tornado, hortum ve tayfunlar okyanustan karaya doğru ilerledikçe ciddi boyutlarda can ve mal kabına yol açmaktadır.

Son 30 yılda dünya genelinde meydana gelen 16 büyük kasırga sonucu binlerce kişi hayatını kaybetmiş ve milyarlarca dolar maddi kayıp oluşmuştur. 1988'de Bangladeş'i vuran kasırgada 1500'den fazla kişi ölmüş kasırga, Hindistan'ın Batı Bengal sahillerini de etkilemiştir. Filipinler'deki Mike tayfunu 1990 yılında 750 kişinin ölümüne, çok sayıda kişi kaybolmasına neden olmuştur. Yine bu olaylara 1991 ve 1997 yıllarında Bangladeş; 1991 ve 1995 yıllarında Filipinler; 1998 yılında Hindistan; 1998 yılında Honduras ve Nikaragua; 1999 yllında Hindistan; 2004 yılında Haiti; 2005, 2012, 2015 ve 2017 yıllarında Amerika Birleşik Devletleri (ABD);2008 yılında Myanmar; 2015 yılında Meksika ve 2016 yılında Haiti kasırgaları örnek olarak sayılabilir.

1971 yılında Dünya Meteoroloji Teşkilatı tarafından, tropikal firtına kaynaklı zararların minimize edilmesi ve zarar gören ülkelerin bilgi alış verişini sağlamak amaciyla "Tropikal Siklon Çalışma Programı" adlı birprogram uygulamaya konulmuştur (Ertürkmen, 2006).

Özellikle küresel ısınma sonucu meydana gelen elnino, okyanus kaynaklı tayfunları oluşturmaktadır. Bu tayfunların yıkıcı etkileri Amerika Birleşik Devletleri, Haiti, Güneydoğu Asya ülkeleri olmak üzere son yıllarda birçok ülkede can ve mal kaybına sebep olmaktadır. 2018 yılında 100 yılda bir gerçekleştiği yetkililerce ifade edilen ve İtalya'nın Sicilya Adası'ndan başlayıp Mora yarım adası üzerinde İzmir kıyılarına kadar ulaşan firtına, bundan sonra Türkiye'nin bu tür doğa olaylarına hazırlıklı olmamız gerektirdiğini göstermektedir. Ayrıca ülkemizde Akdeniz ve Ege'de deniz suyu sıcaklığına bağlı olarak oluşan hortumlarda mal kaybı artışı ve yaralanmalı olayların meydana geldiği görülmektedir.

\section{Tsunami}

Okyanus ya da deniz tabanında daha çok dalma batma zonlarında meydana gelen deprem sonucu taban çökmesi ile oluşan uzun periyotlu deniz dalgasına tsunami denir. Ayrıca deniz tabanında yer değiștirme ve heyelan ile de oluşabilir. Japonya'da 15 Haziran 1896'da meydana gelen ve 21000 kişini ölümüne neden olan deprem sonucu Büyük Meji Tsunamisi'nden sonra dünya dillerinde doğrudan yerini almış bir kavramdır. Daha çok liman bölgelerinde zarara yol açtığı için Japonca'da "liman dalgası" anlamına gelmektedir. Tsunami diğer deniz dalgalarından farklıdır. Deniz tabanının çökmesi ile boşalan alana çekilen su, fiziksel özelliğinden dolayı tepkime ile sahile doğru ilerlemeye başlar. Bu süreçte hızı ve dalga yüksekliği artar. Bundan dolayı da önünü ne gelirse süpürme biçiminde sürükler. Denizin derinliklerinde hissedilmeyen tsunami, sığ kesimlere gelindikçe şiddetli akıntılara dönüşür. Bu akıntının dik yamaçlarda 30 m’ye kadar tırmandığı ifade edilmektedir (Ertürkmen, 2006).

26 Aralık 2004'de Büyük Okyanustaki dalma batma zonunda meydana gelen ve Güneydoğu Asya'da yedi ülkede etkili olan 8,9büyüklügündeki deprem sonucu oluşan tsunami, 11 binden fazla insanın hayatını kaybetmesine neden olmuştur. Yine 11 Mart 2011'de Japonya açıklarında meydana gelen 9 büyüklüğündeki depremde yapısal hasardan 2 kişi ölürken, tsunami nedeniyle 15.866 kişi yaşamını yitirmiștir. Her iki bölgede de depremden hemen sonra denizde cılız bir 
Türkiye'de Afet Yönetimi Ve İs Sağlı̆̆ı̆ Güvenliğ̈i

dalga oluşmuş ve sular kıyıdan uzaklaşmıştır. Daha sonra gelen ikinci dalga denizde ve karada önüne ne geldiyse sürüklemek suretiyle yerleşim birimlerini basmıştır. Tsunami dalgasından kaçamayanlar yerleşim birimlerinde hayatlarını kaybetmişlerdir (Koshimura, Hayashi ve Gokon, 2014).

Tsunami genellikle okyanuslarda ve açı denizlerde meydana gelir. Türkiye'de yapılan çalışmalarda Akdeniz'de Afrika levhasının Anadolu levhası altına dalması neticesinde oluşan Dalma-Batma zonu boyunca meydana gelen deniz tabanı çökmesi ile geçmişte tsunamiler meydana gelmiştir (Yolsal, TaymazveYalçıner 2007; Yolsal, TaymazveYalçıner 2008). 2016 yılında meydana gelen 6.6 büyüklügündeki Bodrum depreminde kısmen tsunami oluşmuştur. 1963 Marmara depreminde de deniz tabanındaki kütle hareketinden kaynaklı dalga yüksekliği küçük de olsa tsunami oluşturduğu kayıtlarda görülmektedir.

\subsubsection{Teknolojik Afetler}

Teknolojinin gelişmesi ve küreselleșmenin beraberinde getirdiği daha çok insan kaynaklı tehlike oluşturduğu afetlerdir. Endüstriyel kaza ve yangınlar, büyük petrol ve doğal gaz sızıntıları, nükleer kazalar, hava ve su kirlenmesi teknolojik afetlere neden olabilirler.

Her geçen gün teknolojinin gelişmesi, endüstrileşmenin artması, kentleşme, buna bağlı kara, hava, demir, deniz taşıma ve ulaşımındaki ilerlemeler, nükleer santral kazaları can ve mal kayıplarına neden olmaktadır (Geray, 1978).

21. yüzyılın en büyük iki gereksiniminden biri olan enerji ihtiyacını karşılama zorunluluğu nükleer teknolojinin daha fazla kullanılmasını zorunlu kılmaktadır (Alevcan, 1995). Bunun sonucu olarak, nükleer santraller sosyal hayatın bir parçası haline gelmeye başlamışlardır. Gelişmiş ülkelerde ihtiyaç duyulan enerjinin büyük bir kısmı nükleer santrallerden sağlanmaktadır. Elbette tehlikesinden dolayı nükleer enerji ve fosil yakıtlardan elde edilen enerji yerine alternatif enerji kaynakları araştırılmaktadır. 2017 yılının başında dünya genelinde yenilenebilir enerjinin toplam ihtiyaç duyulan enerji miktarı içerisindeki payı \%24.8'dir. Geri kalan \% 75.2'lik kısım ise fosil yakıtlar ve nükleer santrallerden sağlanmaktadır (T.C. Enerji ve Tabii Kaynaklar Bakanlığı).

Türkiye'de sanayi bölgelerinin büyük bir kısmının birinci derece deprem bölgesinde yer alması, tektonik yapının coğrafyayı şekillendirmesi ile kara yolu vedemir yolu ulaşımının fayların yoğun olduğu bölgelerden geçmesidepremin hasar derecesini artırabilmektedir. Bununla birlikte, insan kaynaklı Endüstriyel-Nükleer kazalar, Baraj kazaları, Yangınlar afetlere neden olabilmektedir.

\section{AFET YÖNETIM SISSTEMI EVRELERİ}

Afet yönetimi, afet zararlarının önlenmesi ya da azaltılması için, risk analizi ve zarar azaltma, hazırlık, ilk yardım ve müdahale ile yeniden inşa evrelerini içerecek şekilde afetin yönetilmesine denir. Afet yönetiminde tüm kurum ve kuruluşlar sürece dâhil edilmeli ve kaynaklar ortak amaç doğrultusunda kullanılmalıdır (Ergünay, 2005).

Afet sonucunu oluşabilecek can ve mal kayıplarının önlenmesi veya en aza indirilmesi için, yukarıda sayılan tüm afet yönetimi evrelerinin bütünleşik olarak yürütülesi gerekir. Afet yönetim planının toplumun bütün kesimlerini içerecek biçimde planlanması, desteklenmesi, organize edilmesi, gerekli mevzuat düzenlemelerinin yapılması ve kurumsal yapıların oluşturulması veya revize edilmesi, etkili ve verimli uygulamalar için gereklidir. Özetle "Afet Yönetimi" afet riskinin en aza indirilmesi, zararlarının azaltılması, oluşturacağı olumsuz sonuçların önlenmesi veya azaltılması, olası hasarın tahmin edilmesi ve ihtiyaç durumunun tespiti, acil durum müdahale planın oluşturulması, buna yönelik eğitim ve tatbikatların gerçekleştirilmesi, bunun için toplumun tüm kurum ve kuruluşlarıyla kaynaklarının bu ortak amaç doğrultusunda yönetilmesini gerektiren çok yönlü, çok disiplinli, çok aktörlü, oldukça geniş 
Afet ve Risk Dergisi Cilt: 2 Sayı: 1, 2019 (43-63)

Șakir ŞAHIN, İbrahim ÜÇGÜL

kapsamlı bir yönetim sürecidir (AFAD, 2014). Ayrıca erken uyarı sistemlerinin kurulması, varsa mevcutların iyileştirilmesi, öngörü, afet sonrası için etkili ve hızlı ihtiyaç analizinin yapılması, yeniden inşa ve iyileștirme, rehabilitasyon faaliyetleri de Afet yönetimi kapsamına dahil edilmelidir.

Afet yönetiminin amacı, afetin yol açacağı can ve mal kaybı riskini en aza indirmek ve afete en fazla maruz kalanları kurtarmaktır. Ayrıca, doğal çevreyi, kültür ve tabiat varlıklarını koruma altına almak, sosyal hayatın bir an evvel normale dönemsini sağlamak ve öncesinden daha ileri götürmek, toplumun ihtiyaç duyduğu kamu ve özel sektör menşeli hizmetlerin devam etmesi ve sürdürülebilirliğini sağlamak şeklinde ifade edilebilir.

Dolayısıyla afet yönetimi sadece afet anı ve sonrasında yapılacak faaliyetlerle sınırlı değildir. Afet öncesi planlamanın, en az anı ve sonrasındaki müdahale kadar önemli olduğu, hatta afet zararlarının en aza indirilmesinde çok daha büyük etki ettiği bir gerçektir (Geray, 1997; Ergünay, 1998; Ertükrmen, 2006; Kadığlu, 2008; Kadıŏlu, 2017). Tehlikelerden kaynaklanan riskler dikkate alınarak, afet öncesi, sırası ve sonrası için yapılan çalışmalar etki dercesine göre olay, acil durum ve afet olarak tanımlanabilir. Beklenen riskin gerçekleşmesi durumunda sonuçlar küçük ise, buna "olay", bundan daha büyük fakat yerel imkânlar ile baş edilebilir düzeyde ise buna "acil durum", ancak acil durum mevcut imkânlar ile baş edilemeyecek kadar büyük ise buna "afet " denilmektedir (Kadıoğlu, 2017; Şekil 3). Günümüzde afet yönetimine, yukarıda belirtilen üç ana evreye ilave olarak, tahmin ve erken uyarı sistemlerinin olușturulması, afetlerin takibi, etki derecesi ve ihtiyaçların tespiti gibi alt evreleri de dâhil etmek gerekir. Afet yönetim sisteminde hadiseler, "olay, acil durum ve afet" olarak sınıflandırılır (Kadığlu, 2017).

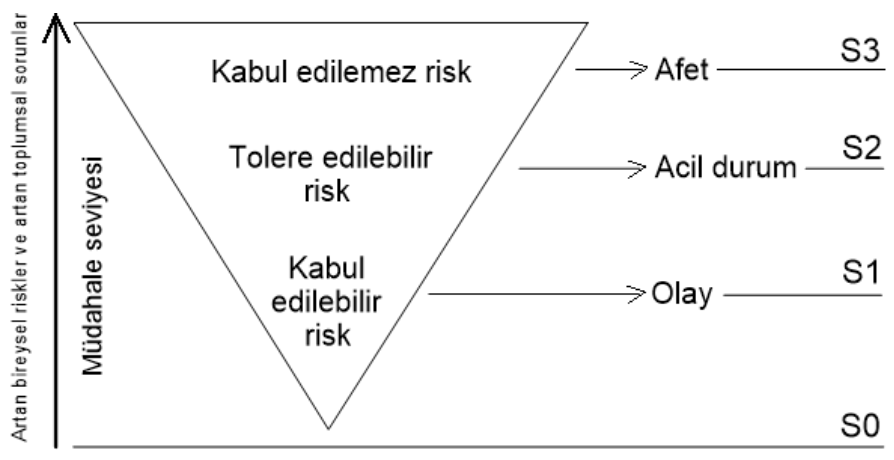

Şekil 3. Makul bir Havuç Diyagramına göre farklı 3 risk seviyesi (S1, S2, S3) ve bu seviyelere göre olay, acil durum ve afet yönetimi aşamaları (Kadığlu, 2017).

\subsection{Afet Planinin Evreleri}

Afet planı evrelerini "afet öncesi, afet sırası ve afet sonrası" olarak üç başlık altında toplamak mümkündür (Geray, 1978). Bu evrelerin beşli olarak sınıflandırılması gerektiği yönünde görüşler de vardır. Buna göre Ergünay (1996) bu safhaları,önleme ve zarar azaltma, afetlere karşı hazırlık, kurtarma ve ilkyardım, iyileștirme ve yeniden inşaşeklinde sinıflamıştır.Bu çalışmada ise Kadıŏlu (2008) ve Ergünay (1996)'dan hareketle afet planı evrelerini afet öncesi risk yönetimi ve afet sonrası kriz yönetimi șeklinde tanımlamanın uygun olacağı düşünülmüştür. Risk yönetiminin birinci aşaması risk analizi ve zarar azaltma, ikinci aşaması ise, hazırlıktır. Birinci aşamada afet olmadan önce tahmin ve erken uyarı sistemlerinden faydalanılmalıdır. Kriz yönetiminin birinci aşaması ilk yardım ve müdahale, ikinci aşaması ise yeniden inşadır. Afet sonrası müdahaleden önce etki analizinin yapılması gerekmektedir. Afet planı çerçevesinde yürütülen faaliyetlerin birbirini tamamlaması nedeniyle bu evrelerin birbirini takip etmesi gerekir. Bu evrelerin arasındaki ilişki ve bağımlılık Șekil 4'de görülmektedir. Burada verilen tüm 
Türkiye'de Afet Yönetimi Ve İs Sağlığı Güvenliği

evreleri kapsayan iyi bir afet yönetimi planının hazırlanması, iş sağlı̆̆ı ve güvenlinin sağlanması açısından hayati öneme sahiptir.

Dünyadaki mevcut durumdan hareketle afetlerin tümüyle önlenmesi mümkün değildir. $\mathrm{Bu}$ nedenle afet zararlarının en az indirilmesi amaçlanmakta ve afet yönetim planları da ona göre hazırlanmaktadır (Geray, 1978). Bunun gerçekleşebilmesi için doğal ve teknolojik afetler ve evrilme durumları da dikkate alınarak Şekil 4'de verildiği üzere bütünleşik ve günün şartlarına göre çağdaş normlarda hazırlanmış afet yönetim planlarına ihtiyaç vardır.

Afetten önce ve afet sırasındaki uygulamalar 18.12.2013 tarihinde yürürlüğe giren Afet ve Acil Durum Müdahale Hizmetleri Yönetmeliği (AADMHY)hükümlerine göre yürütülmektedir. Buna göre, günlük hayatı önemli ölçüde etkileyen afetlere yönelik tedbir almada AFAD bünyesinde oluşturulan "Afet ve Acil Durum Danışma Kurulu"sorumludur. Kurul, Aafet ve acil durumlardan korunmak, risklerini azaltmak, afet ve acil durum sonrası yapılacak faaliyetler hakkında öneriler sunmak, politikaları ve öncelikleri belirlemek amacıyla AFAD Başkanı veya belirleyeceği başkan yardımcısının başkanlığında, Dışişleri Bakanlığı, İçişleri Bakanlığı, Boğaziçi Üniversitesi Kandilli Rasathanesi ve Deprem Araştırma Enstitüsü (KRDAE), Maden Tetkik ve Arama Genel Müdürlügü (MTA), Türkiye Bilimsel ve Teknolojik Araştırma Kurumu, Türkiye Kızılay Derneği'nden daire başkanı düzeyindeki birer temsilci ile afet ve acil durumlar konusunda çalışmaları bulunan ve Yükseköğretim Kurulu tarafından bildirilecek en az on üniversite öğretim üyesi arasından başkan tarafından belirlenecek beş üyenin de dahil olduğu yetkili organdır. Kurul, yılda en az iki kez toplanır. Ayrıca ihtiyaç halinde Kurul, başkanın çağrısı üzerine olağanüstü toplanabilir.Kurulun sekretaryasını başkanlık yürütür.Afet konularında alınacak tedbirler konusu “İçişleri Bakanlığı Afet ve Acil Durum Yönetimi AFAD Başkanlığı'nın görev alanı içerisine girmektedir.

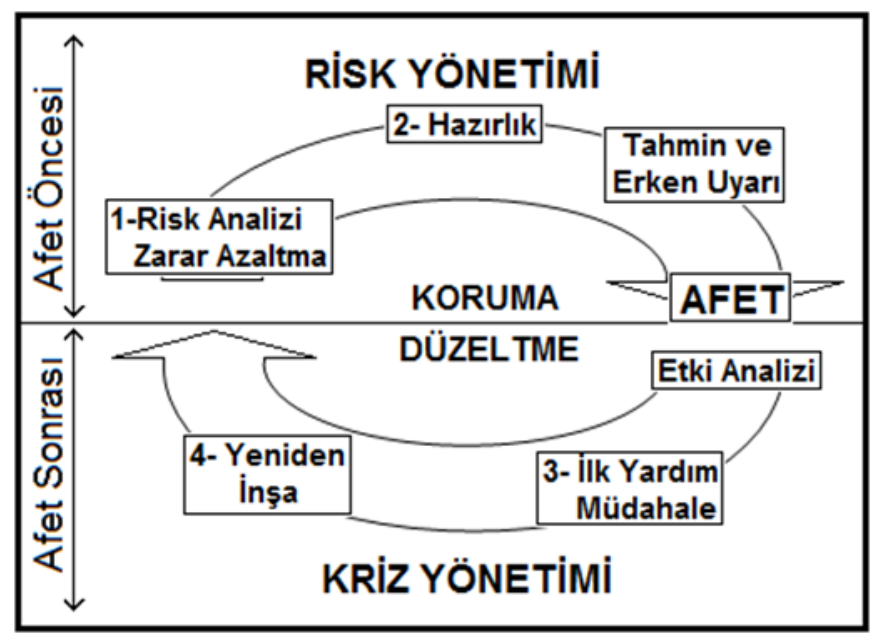

Şekil 4. Modern ve bütünleșik afet yönetim sistemi ve evreleri (Kadığlu, 2008 ve Ergünay 1996'dan yararlanılarak çizilmiştir)

\subsubsection{Risk Yönetimi}

$\mathrm{Bu}$ safha afet meydana gelmeden önceki risk yönetimi aşamasıve bunun risk analizi -zarar azaltma ve hazırlık evrelerini oluşturmaktadır. Burada asıl amaçzararın minimize edilmesidir. Toplumun afetten etkilenmesinin önüne geçilebilmesi için afet öncesi teknik, yasal düzenlemelerin yapılması ve organizasyon planlarının hazırlanması gerekir. Ayrıca afet riskinin ortadan kaldırılması ülke kalkınmasıaçısından son derece önemlidir. Bundan dolayı afet öncesi planlama sürecinde, kalkınmada etkin olan tüm unsurların, kurum ve kuruluşların, bireylerin bu sürece dahil edilmesi, bireysel zararların en aza indirilmesi için bireye yönelik eğitim 
Afet ve Risk Dergisi Cilt: 2 Sayı: 1, 2019 (43-63)

Şakir ŞAHIN, İbrahim ÜÇGÜL

programlarının hazırlanması ve bu programlara katılımın sağlanması gerekmektedir. Hazırlık aşamasında ise tahmin ve erken uyarı sistemlerinin etkin bir biçimde kullanılmasında fayda vardir.

Afetlerin etkisi gün geçtikçe ekonomik ve sosyal hayatı daha fazla etkilemektedir. Afet riskinin azaltılmasında sürecin kalkınma planından başlanılmasında fayda vardır. Bilhassa afete maruz kalan bölgelerde yatırımların planlama, projelendirme ve uygulama süreçlerinde afet risklerinin dikkate alınması can ve mal kayıplarının en aza indirilmesinde ve yeni risklerin ortaya çıkışını önleyecektir (Ayanoğlu, Düzyol, İlter ve Yılmaz, 1996).

Afet öncesi Afet Planının bir parçası olan risk planlarının ülke ihtiyaçlarına göre il düzeyinde diğer acil durum planlarıyla koordinasyonun sağlanması ve İçişleri Bakanlığı, ilgili kamu kurum ve kuruluşları, meslek odaları ve üniversitelerin ve mahalli idarelerin görüşleri alınarak yapılması gerekir. Planların öngördüğü şekilde halka eğitim verilmeli, kurumlar ve örgütler gerekli önlemleri koordineli bir biçimde almalıdırlar. Belediyeler, belediye sorumluluk sahaları dışında doğal afet ve yangın meydana gelmesi halinde de afetten etkilenen bölgelere gerekli yardım ve desteği sağlamalıdır. Belediye Kanununa göre bu yetkiye sahiptirler.

\subsubsection{Risk Analizi ve Zarar Azaltma}

$\mathrm{Bu}$ evre Afet yönetim planının ilk aşamasını oluşturur. Bu aşama afet yönetimi açısından çok önemlidir. Yürütülen çalışmalar ülke ve bölge bazında yapılmakta olduğundan çok geniş bir alanı, dolayısıyla çok sayıda yerleşim birimini ve nüfusu ilgilendirmektedir (Ergünay, 1999).

Risk analizi ve zarar azaltma evresi, afet için uygulanacak yasal düzenlemelerin ülke ihtiyaçlarına göre oluşturulması, yapılanma ve doğal afetlere ilişkin yönetmeliklerin yeniden düzenlenmesi, afet oluşma riskinin yerel ve bölgesel, hatta ülke bazında yeniden belirlenmesi ve tehlike haritalarının hazırlanmasından oluşmaktadır (Ergünay, 1996). İlave olarak ihtiyaç duyulan akademik ve teknik düzeyde araştırmaların yapılması ve sürdürülmesi, ülke bazında gerekli tüm verilerin toplanması için deprem ve diğer kayıt ağlarının oluşturulması ve verilerin sürekli olarak kaydedilmesi ve değerlendirilmesi, toplanan ve kullanılabilir düzeye getirilen verilen kamu nezdinde bir veri merkezinde toplanması ve ilgili kurumların kullanımının sağlanması, erken uyarı ve kontrol, toplumun tüm kesimlerini içerecek şekilde eğitim programlarının hazırlanması ve uygulanmasını kapsayan geniş çaplı çalışmalar bu safhanın içerisinde yer almaktadır. Afet riskini önleyici ve afet zararını azaltmaya yönelik mühendislik tedbirlerinin uygulanması ve sürdürülebilir kılınması risk analizi ve zarar azaltma safhasında yürütülmesi gereken ana faaliyetler alarak sayılabilir.

\subsubsection{Hazırlık}

Hazırlık evresi, yerleşim merkezi bazında afet olmadan önce, risk analizi ve zarar azaltma evresi çalışma sonuçlarından hareketle afetin olası sonuçlarına yönelik ihtiyaçların belirlenmesi, acil eylem planın hazırlanmasını kapsamaktadır. Ayrıca tahliye sürecini şekillendirilmesi, toplanma merkezi belirlenmesi, il düzeyinde yerleşim birimi Kurtarma ve Acil Yardım Planlarının hazırlanması ve gelişen şartlara göre güncellenmesi, afete müdahale ve ilk yardım aşamalarında duyulacak ihtiyaç malzemelerinin yer alacağı bölge teçhizat merkezlerinin kurulması ve kritik ihtiyaç malzemelerinin stoklanması çalışmalarını içermektedir. Ayrıca erken uyarı sistemlerinin, çalışır olup olmadığının kontrol edilmesi, işletilmesi ve değişen koşullara göre güncellenmesi faaliyetleri bu evrenin kapsamına girmektedir.

Hazırlık evresinin bir süreci olan Acil Eylem Planı, afet tehdidi altında bulunan bir yerleşim biriminin karşılaşacağı tehlikeleri, bu tehlikelerin oluşma riskinin belirlenmesi ve oluşması durumunda uğranılacak zarar ve kayıpları ortaya koyan ve bunların en aza indirilebilmesi için görevlendirilecek kurum kuruluş ve bireylerin hangi yetkiyle ve ne zaman görevlendirileceği ve hangi kaynaklarını kullanılacağını açıklayan plandır (Ergünay, 1996; 1999). 


\subsubsection{Kriz Yönetimi}

$\mathrm{Bu}$ aşamada afet yönetim planının afet sırası ve sonrasında yürütülecek faaliyetler mevcut kaynak ve imkânlar dâhilinde en hızlı ve etkili biçimde afetin etkilediği yerleşim biriminde kullanılmasının amaçladığı ve arama kurtarma, sosyal hayatın normale döndürülmesi faaliyetlerinden oluşan bir evredir. Ayrıca olağanüstü koşullar altında uygulanacağı için bu faaliyetlerin çok iyi planlanmış olması, koordinasyonun sağlanması gerekir (Ergünay, 1998).

Afetin hemen sonrasında alınan acil önlemler ve yapılan çalışmaların amacı mümkün olan en kısa zamanda en fazla hayat kurmaktadır ve yaralıların sağlıklarına kavuşmalarını sağlamaktır. Ayrıca afet sonrası oluşacak tehlike ve risklerden afetin etkilediği kişilerin can ve mallarının korunması ve toplumun ihtiyaçlarının bir an evvel karşılanması ile afetin etkilediği bölgede sosyal hayatın normale dönmesi için gerekli çalışmaların yapılması faaliyetleri, bu çalışmaların dâhilindedir. Afet anı ve sonrasında yapılan çalışmalar, ilk yardım ve müdahale ile yeniden inşa süreçlerinden oluşmaktadır.

\subsubsection{1. İlk Yardım ve Müdahale}

İlk yardım ve müdahaleevresi afet yönetim planının afetin oluşmasıyla başlayan afetin türü, büyüklüğü ve afetin meydana geldiği alanın özelliklerine göre azami 2 aylık bir süreyi kapsayan faaliyetlerin bütünüdür (Ergünay, 1996). Bu aşamada yürütülen faaliyetlerin amacl, mümkün olan en kısa sürede olaya müdahale etmek, arama-kurtarma faaliyetleri çerçevesinde azami sayıda can kurtarmak ve ilk yardımla yaralıları tedavi etmek, toplumun gıda, barınma, ilaç, güvenlik gibi zaruri ihtiyaçlarının karşılamasını sağlamaktır (Ergünay, 1998). Bu safha iletişim, ulaşım, çevre ve insan sağlığı, hasar tespiti, yıkılan binaların kaldırılması, yangın, patlama ve bulaşıcı hastalıkların oluşturacağı ve afetin olumsuz etkilerini artıracağı durumlara karşı yürütülecek faaliyetleri de içermektedir (Ergünay, 1996).

Ülkemizde afet sonrası ilkyardım ve müdahale aşamasında yürütülecek faaliyetleri ve bu faaliyetlerin uygulanması için "Afet ve Acil Durum Müdahale Hizmetleri Yönetmeliği" hazırlanmıştır. 26/08/2013 tarihinde yürürlüğe giren yönetmeliğin amacı, afet ve acil durumlara müdahalede ihtiyaç duyulacak tüm kaynakları ulusal ve yerel düzeyde planlamak, bu kaynakların olay bölgesine hızlı ve etkin bir șekilde ulaștırılmasını sağlamak, müdahale hizmetlerini ve bu hizmetlerin koordinasyonundan sorumlu ana ve destek çözüm ortaklarının ve yerel düzeyde sorumlu birimlerin görev ve sorumlulukları ile planlama esaslarını belirlemektir. Yönetmelik, afet ve acil durumlarda müdahale hizmetlerini yürütecek bakanlıklar, kamu kurum ve kuruluşları, valilikler, kaymakamlıklar, özel ve özerk kuruluşlar, sivil toplum kuruluşları ile gerçek kişilerin görev ve sorumlulukları, bunlar arasındaki işbirliği, koordinasyon ve karşıllklı yardımlaşma esaslarını kapsar.

\subsubsection{Yeniden İnşa}

$\mathrm{Bu}$ aşamanın amacl, afete maruz kalmış bölgelerin haberleşme, ulaşım, temel ihtiyaçlar, elektrik, kanalizasyon, eğitim, kalıcı konut yapımı, ekonomik ve sosyal hayatın normale dönmesi için gerekli tüm çalışmaları yapmaktır. Yeniden yapılanma faaliyeti kriz yönetiminin yıllar bazında en uzun süren evresidir (Ergünay, 1996).

Yeniden inşa evresinin iyi uygulandığı örneklerden birisi 23 Ekim 2011 Van depremidir. 1999 Gölcük depreminde görülen panik havası çok kısa bir sürede atlatılmış ve hasar tespit çalışmalarının ardından en kısa sürede yeniden inşa evresine geçilmiştir.

Diğer bir örnekte ise, 17 Ağustos - 12 Kasım depremleri sonrasında 4133 Sayılı Kanun'a göre afetzedelere maddi yardımda bulunulmuştur. Toplamda 11,7 Milyon TL kredi o tarihlerde yürürlükte olan 7269 Sayılı Kanun'un 29. maddesine göre yüzde metodu ile ödemeler beş safhada gerçekleșmiștir (Ertürkmen, 2006). Bu uygulamadan en fazla Sakarya ili faydalanmıștır. 
Afet ve Risk Dergisi Cilt: 2 Sayı: 1, 2019 (43-63)

Şakir ŞAHIN, İbrahim ÜÇGÜL

Sakarya ilini Düzce ve Kocaeli illeri takip etmiştir (Şekil 5). Konutlar, alt yapı maliyeti hariç tutularak iki yılı ödemesiz faizsiz yirmi yıl vadeli olarak kredilendirilmiştir.

Depremden sonra hak sahibi olan afetzedelerin başka yerleşim birimlerinden hazır konut alabilme imkânı da sağlanmıştır. 0 dönem afetzedelere verilen kredilerin büyük bir kısmı yine deprem bölgesinde yeniden inşa edilen konutların alımında kullanılmışlardır (Ertürkmen, 2006).Orta hasarlı konutlar için afetzedelere yaklaşık 70 milyon TL kredi 7.269 Sayılı Kanunun 29. Maddesine göre yüzde metodu ile 4 dört safhada ödenmiştir. Bu şekilde depremden zarar gören illerde yeniden inşa evresinde ciddi anlamda kaynak kullanılmıştır.

Yeniden inşa aşamasında bunlar yapılmışken, 1999 depreminin hemen sonrasında etki analizinin yapılamaması nedeniyle ilk yardım ve müdahalede geç kalınmıștır. Kamunun ne yapacağını bilememesi kayıpların artmasına sebep olmuştur. Afet esnasında insanlarda kaybolmuşluk hissi, panik, aşırı korku, ne yapacağını bilememe gibi durumlarla karşılaşılmaktadır. Diğer taraftan afetzedelerde yakınlarından dolayı ciddi kaygılar oluşmuş, buna bağlı olarak arama kurtarma ekipleri ile zaman zaman karşı karşıya gelinmiştir. Neyse ki bu durum daha sonraki depremlerde alınan önlemlerle birlikte ortadan kalkmıştır.

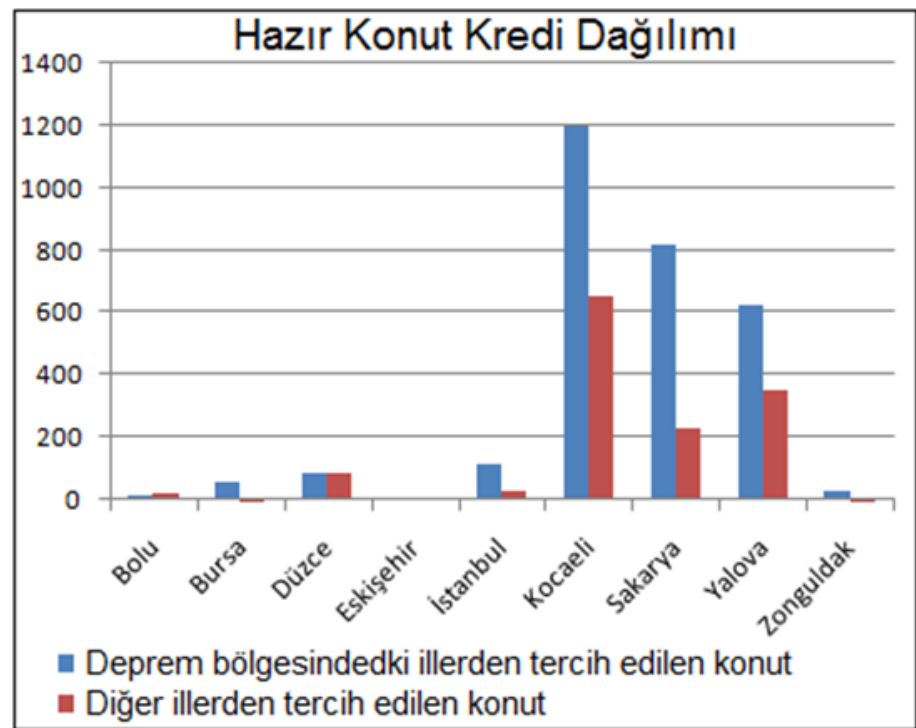

Şekil 5. 1999 Gölcük depremi sonrasında illere göre hazır konut kredi kullanımı dağılımı (Ertürkmen, 2006).

\section{BÜTÜNLEŞIK AFET YÖNETIMI VE İ̧ SAĞLIĞI GÜVENLİĞi}

Günümüze kadar değişik şekillerde tanımlanmış olmakla birlikte günümüzde devlet, toplumun örgütlenmiş ve en büyük siyasal kurumuna dönüşmüş halidir. Doğal ve teknolojik afetler, siyasal olarak örgütlenmiş bu kurumun hazırlıklı olmasını gerektiren önemli olaylardır. Devlet afetle yasal düzenlemeler ve bireyi sürecin içerisine dâhil ederek mücadele eder (Yavaş, 2001). Bütünleşik afet yönetim sistemi, afet ve acil durumlara bağlı kayıpların önlenmesi için tehlike ve risklerin önceden tespit edilmesi, önlemlerin alınması, etkin mücadele için koordinasyonun sağlanması ve afet sonrasında iyileştirme çalışmalarının bir bütün olarak yürütülmesidir (Kadıŏlu, 2008; Macit 2016; AFAD, 2018 ).

Afet yönetimin ana iki evresinden biri olan risk yönetimi faaliyetleri 6331 sayılı İş sağlı̆̆ı ve Güvenliği Kanunu (ISGK)ile yürütülmektedir. Bu kapsamda kurumlardan tesisin afet yönetimi için hazırladıkları acil durum planlarının yanı sıra, yeni yapılan yasal düzenlemeler ile birlikte 
Türkiye'de Afet Yönetimi Ve İs Sağlı̆̆ı Güvenliğgi

kriz yönetiminin gereği olarak afet Planının hazırlanması istenmektedir. Diğer taraftan aynı yasal düzenlemeler çerçevesinde yerel yönetimler bulundukları yerleşim birimleri için afet yönetimi planlarını hazırlamakla yükümlüdürler.

18 Haziran 2013 tarihinde 28681 sayılı Resmi Gazete de yayınlanan İș Sağlığı ve Güvenliği Kanunu'na göre işyerlerinde, mutlak surette sertifikalı eğitimlerin yapılması, hazırlanan risk analiz raporlarının sonucuna göre afet planının hazırlanması, uygulamalı tatbikat eğitimlerinin verilmesi ve yapılacak tüm bu planlamaların çalışan her bir bireye tebellüğ edilmesi istenmektedir.

2013 yılında yürürlüğe giren (AADMHY) daha çok ilk yardım ve müdahale ile yeniden inşa evrelerini düzenlemektedir. Bu evreler de kriz yönetimin aşmalarıdır. Oysa iyi bir afet yönetimi risk yönetimi ile kriz yönetimi evrelerini içermelidir. Ülkemizde işyerlerinde afet planlarında risk analizi 6331 sayılı İSGK ile sağlanmaktadır. Etkin bir afet yönetim planının hazırlanması için AADMHY ile İSG yönetmeliklerinin bir arada uygulanması gerekmektedir. Dolayısıyla iş sağlığı ve güvenliği afet yönetiminde ayrı düşünülemeyeceği çok net bir biçimde görülmektedir.

AADMHY ve İSG yönetmelikleri esas alınarak afet yönetiminin iki açıdan stratejik öneme sahip olduğu söylenebilir:

Sürdürülebilir Kalkınma: iyi bir afet planı hazırlamadan ve bunu dikkate almadan çevre ile ilgili sorunları azaltmak ve sürdürülebilirbir kalkınmayı sağlamak mümkün değildir (Kadığlu, 2017). Doğal afetlerin olumsuz etkileri çoğunlukla geri kalmış ve gelişmekteolan ülkelerde gözlemlenmektedir. Bu ülkelerin kalkınma hızı doğal afetler ile yavaşlamakta bazen de gerilemektedir.Afetlere karşı önlem alınmadığı sürece, büyük çaba ve fedakârlıklar ile elde edilen kazançlar bir doğal afetle birlikte yok olabilmektedir.

Ülkemizde zaman zaman doğal ve teknolojik afetler meydana gelmekte ve kayıplar oluşmaktadır. 17 Ağustos 1999 Gölcük'te7.4 büyüklüğünde meydana gelen ve hemen hemen tüm Marmara Bölgesini etkileyen deprem, büyük oranda can ve mal kaybına sebep olmuştur. 1999 yılına kadar çok da önemsemediğimiz deprem gerçeği ile karşılamamız genel geçer doğrular olarak kabul ettiğimiz davranışlarımızın sorgulamasına neden olmuștur. Yıkım ve can kayıplarına neden olan afetler, toplumca bütün olarak afet ve afet yönetimi konusunda hassas olunması gerektiğini ve bu konuda eğitimin ihtiyaç olduğunu göstermiştir.

Doğal afetlerle mücadelede ilk önce kentsel dönüşümün etkili olarak uygulanması ve bu konunun toplum tarafından benimsenmesinin sağlanması gerekmektedir. Kentsel dönüşüm, salt bir doğal afet sonucu yıkılan binaların temizlenmesi değil, planlama dâhilinde hem kentsel hem de sosyal anlamda çağdaş normlara sahip yerleşim birimlerinin inşa edilmesidir. Diğer bir deyişle doğal afet açısından güvenli ve sosyal hayat açısından yaşanılabilir kentlerin oluşturulmasıdır. Bu konuda Çevre ve Şehircilik Bakanlığı'nın yanı sıra belediyelere de hem halkın bilinçlendirilmesi, hem de yasal olarak kentsel dönüşümün uygulanması noktasında büyük görevler düşmektedir. Sağlıklı bir kentsel dönüşüm yapılmış bir yerleşim merkezinde afet yönetim planın etkin bir şekilde uygulanması durumunda, bir afetinmeydana gelmesiyle toplumun uğrayabileceği olası can kaybı, yaralanma, ruhsal rahatsızlıklar, hasara bağlı yıkım ve kayıplaren aza indirilecektir.

Afet Riskinin Azaltılması ve Kaynakların Verimli Kullanılması: Afet riskleriniazaltmaya yönelik afet yönetim planlarının oluşturulması sürdürülebilir bir kalkınma için en mantıklı yatırımdır.Risk analizi ve zarar azaltma ile hazırlık evrelerinin gereği yürütülmeyen faaliyetler, afet sonrası can ve mal kaybı olarak karşımıza çıkmaktadır. Bu yüzden iyi bir afet yönetim planın parçası olan risk yönetimi ile riskleri tespit etmek, analiz etmek ve yönetmek kaynakların verimli 
kullanılması açısından önemlidir. Ayrıca mal-mülk, çevre, kültür ve tabiat varlıklarını muhafazası, iş sürekliliği ve verimliliği, hizmetlerin devamının sağlanmasıgereklidir.

1900 'lü yıllardan bu yana ülkemizde meydana gelen doğal afetlerde yaklaşık 85.000 civarında can kaybı ve milyarlarca lira maddi kayıp oluşmuştur. Sadece 45 saniye süren 1999 Gölcük depreminin ilk 72 saatlik maddi kaybı bu günkü değerle yaklaşık 44 milyar liradır (TBMM, 1999). Deprem müdahale sonrası iyileştirme çalışmaları için harcanan kaynak ise yaklaşık bunun üç katıdır.

Ülkemizde doğal afetlerin büyük bir çoğunluğu krize dönüşmektedir. Oysa herhangi bir doğal olay oluşmadan önce risk analizi yapılsa, bu durumun krize dönüşmesi önlenebilecek ve kaynaklar daha verimli kullanılacaktır. Buradan hareketle bir olay olmadan ya da afete dönüşmeden önce afete hazırlıklı olacak şekilde stratejilerin geliştirilmesi, can ve mal kayıplarının önüne geçilmesi veya en azından minimize edilmesi açısından önemlidir. Bununla birlikte risk analizine dayanan bir afet yönetimi, çevre ve ekosistemin korunmasını,toplumun yaşam kalitesinin yükseltilmesini sağlamalıdır.

\subsection{Afet Yönetiminde Karşılașılan Sorunlar}

\subsubsection{Mevzuattan Kaynaklanan Sorunlar}

7269 sayılı Umumi Hayata Müessir Afetler Dolayısıyla Alınacak Tedbirlerle Yapılacak Yardımlara Dair Kanun ve 88/12777 sayılı Afetlere İlişskin Acil Yardım Teşkilatı ve Planlama Esaslarına Dair Yönetmelik kaldırılarak yerine 26.08.2013 tarihinde AADMHY yürürlüğe konulmuştur.

$\mathrm{Bu}$ yönetmeliğe göre, afet ve acil durum hizmetleri, hazırlık, müdahale ve iyileştirme evrelerinden oluşmaktadır. Hizmetlerin tam olarak yapılması ve bütünlügünün korunması ile hizmetler arası ilişkinin gözetilmesi zorunludur. Yapılacak planlarda gerçekleştirilecek tüm hizmetler esas alınarak müdahale modellerin oluşturulması istenmektedir. Modellerin, ulusal düzeyde koordinasyon ve saha destek ekip ve alt ekiplerini, yerel düzeyde ise operasyon ve lojistik ekip ve alt ekiplerini içermesi gerekir. Yönetmelikle planlamanın, model oluşturma ve kapasite geliştirme çalışmaları ile ulusal ve yerel düzeyde, muhtemel afet türlerine göre, karşılaşılabilecek operasyon risklerine ve yaşanabilecek en kötü şartlar dikkate alınarak oluşturulması istenmektedir (AADMHY madde 5).

$\mathrm{Bu}$ yönetmelik AFAD koordinatörlüğünde uygulanmaktadır. AFAD’ın kuruluşundan önce afetle ilgili çok sayıda kurum yetkili olması nedeniyle afet yönetiminde çok başlılığın beraberinde getirdiği eşgüdüm sorunu yaşanmıştır.

$\mathrm{Bu}$ yönetmelik afet yönetim evrelerinden hazırlık, acil müdahale ve ilk yardım ile yeniden inşa (yapılanma) evrelerini kapsamaktadır. Bundan dolayı, bu yönetmelik daha çok kriz yönetimine yöneliktir. Türkiye özellikle kriz yönetiminde başarılıdır. Örneğin AFAD bu yönetmelikle, Van depremi, Soma ve Ermenek maden kazaları, Suriye Mülteci sorunlarına müdahale ve yeniden inşa konusunda başarı sağladığı görülmektedir. Yukarıda açıklandığı üzere, afet yönetimi bu evrelerle birlikte risk analizi ve zarar azaltma evrelerini içermelidir. Bu yönetmeliğin eksik tarafı budur.

Ülkemizde doğal afetlerin yaşanma biçimine bakılırsa, afet yönetiminin ilk iki evresi olan rriskanalizi ve zarar azaltma ile hazırlık konusunda maalesef istenen başarı yakalanamamıștır. Deprem, fırtına, su baskını, küresel ısınma ve çarpık kentleşmeden dolayı afetlerin etkilerinde bir artış söz konusudur. Bu durum ilgili yönetmeliğin eksikliğinden kaynaklanmaktadır. Afet yönetiminin dört evresinin birbirini tamamlar nitelikte uygulanması halinde afet zararlarının azaltılmasında başarılı olacağı muhakkaktır. 
Türkiye'de Afet Yönetimi Ve İs Sağlı̆̆ı Güvenliğgi

\subsubsection{Uygulamadan Kaynaklanan Sorunlar}

Afet sonrasında uygulanankrizyönetimi sürecinde değişik sorunlar ile karşılaşılmaktadır(Esen, 2000). Kriz yönetiminde, mevcut kriz yönetiminin eksiklikleri, ulaşım hizmetlerinde yaşanan aksaklıklar, altyapı hasarları, müdahale ve tahliye esnasında yaşana sorunlar, asayiş ve güvenlik sorunları, insani yardımlarınalınması, kaydı, depolanması ve dağıtımı esansında yaşanan sorunlar ve geçici barınma sorunları ile karşılaşılmaktadır (Yılmaz, 2001). Bu sorunların giderilmesinde yürütmeye bağlı tüm birimler sorumluluklarını yerine getirmeleri gerekmektedir. Bu sorumluluklar (Şenalp, 2000);

- Risk ve Kriz yönetimini içerecek şekilde, diğer bir deyişle Afet Yönetiminin tüm evrelerini kapsayacak şekilde yasal düzenlemelerin yapılması ve uygulama noktasında denetimlerin artırılması (Şekil 4),

- Afet öncesinde Afet risk analizinin yapılması, erken uyarı sisteminin kurulması, arama kurtarma, ilk yardım, geçici ve sürekli barınma alan ve projelerinin hazırlanması,

- İmar planlarının günün şartlarına göre hazırlanması, mevcut planların tadilatının yapılmasının sağlanması,

- 29.16.2001 tarihinde uygulamaya başlanan 4708 nolu Yapı Denetim Yasası'nın etkin bir şekilde uygulanmasının sağlanması ve bu yasada mevcut olan uygulamaya dayalı eksikliğin giderilmesi,

- Denetime yönelik, yapı polisini ve uzmanlık yargıçlık sisteminin oluşturulması,

- Bundan sonra inşa edilecek endüstriyel kuruluşların, barajların, enerji santrallerinin, yerleşim alanlarının ülke kalkınması ve bölgeler arası gelişmiş farkının gözetilerek planlanması.

- Küresel ısınma ve kuraklık tehlikesini de dikkate alarak endüstriyel kuruluşların insan sağlığı ve çevre açısından oluşturacağı zararın en aza indirilmesine yönelik düzenlemelerin yapılması,

- Kırsaldan kente göçün devam ettiği ülkemizde, kentlerin insanca yaşanılabilir hale getirilmesidir. Bilimsel veriler dikkate alınarak yapılacak düzenlemeler ile uygulamadan kaynaklı sorunlar en aza indirilebilir.

\subsection{Afet Yönetiminde Yeni Yaklaşımlar}

2009 yılında AFAD’ın kurulması ile ülkemizde afete bağlı kriz yönetimi konusunda çok önemli gelişmeler olmuștur. Bu gelişmelerin temelinde Gölcük ve Düzce depremleri yer almaktadır. Nüfusun yaklaşık \%31'nin yaşadığı (TUIK, 2018) veülke gelirlerinin \%45'nin sağlandığı bu bölgede meydana gelen yıkım düzeyindeki can ve mal kaybı, yapısaldeğişiklikleri de beraberinde getirmiştir. Bunlardan bir kısmıulusal düzeyde kurumsal (AFAD örneği) ve yasal düzenlemeler, diğer kısmı da uluslararası düzeyde gerçekleşmiştir.

2009 yılında, Türkiye Acil Durum Yönetimi, Afet İşleri ve Sivil Savunma Genel Müdürlükleri lağvedilerek 24.06.2018 tarihine kadar Başbakanlığa bağlı Afet ve Acil Durum Yönetimi Başkanlığı (AFAD) kurulması ile ülkemizde kriz yönetimi konusunda önemli gelişmeler olmuştur. Bu tarihten sonra AFAD İçişleri Bakanlığı'na bağlanmıștır. AFAD kurumsal olarak Amerika Birleşik Devletleri'nde bulunan FEMA (Federal Emergency Management Agency)'nın yapısına benzemektedir. Ancak AFAD'ın görev ve sorumlulukları daha fazladır. 1999 Gölcük ve Düzce depremlerinden sonra Dünya BankasıTürkiye Acil Durum Yönetimi GenelMüdürlügü’nün mevcut afet durumunu yönetemeyeceğini ileri sürmüş hatta yardımşartlarından biri olarak yeni bir kurumun oluşturulmasını şart koşmuştur. Çünkü bu kurumun yetkileri Afet İşleri ve Sivil Savunma GenelMüdürlükleri ile Kızllay'ın yetkileri ile çakışmakta olduğu ileri sürülmüştür. 0 dönem sorunun çözümü için, Afet isleri Genel Müdürlüğü ile FEMA "Doğal ve DoğalOlmayanTeknolojik Afetleri Önleme ve Müdahale Etme Alanında işbirliği Niyet Protokolü'nü" imzalanmıştır. Bu protokol 10 Aralık 1999 tarih ve 99/13872 sayılı Bakanlar 
Afet ve Risk Dergisi Cilt: 2 Sayı: 1, 2019 (43-63)

Şakir ȘAHİN, İbrahim ÜÇGÜL

KuruluKararıylaonaylanmıștır. 16 Haziran 2000 tarihinde, Türkiye ile ABD arasında "Afetlere On Hazırlık ve Afet Yönetimi Alanında Türk-Amerikanişbirliği 2000 Yılı Çalışma Planı" imzalanmıștır. Sürecin sonunda kurumsal anlamada FEMA ile benzer olan AFAD kurulmuș ve Türkiye'de 26.08.2013 tarihinde Afet ve Acil Durum Müdahale Hizmetleri Yönetmeliği yürürlüğe konularak Afet Yönetimde yeni bir yaklașım ortaya konulmuștur.

Afet oluşumuna ilişkin kamuoyuna yapılan bilimsel olmayan ve mesnetsiz açılamalar bu alanda yaşanan en önemli sorunlardan birisidir. Bu sorunun çözümü, çalışmaların bilimsel temelde yapılması ve sürdürülmesi amacıyla, 21 Mart 2000 tarihinde "UlusalDeprem Konseyi"oluşturulmuştur. Ancak bu kurul 06.01.2007 tarihinde lağvedilmiştir. Mevcut yasal düzenlemeye göre afetle ilgili kamuoyuna açıklama yetkisi AFAD’a verilmiștir.

Afet sonucu oluşan hasara bağlı kaybın finanse edilmesi en önemli sorunlardan biridir.Yeniden inşa (yapılanma) sürecinin kapsamına giren finansman sorunu, toplanan ulusal ve uluslar arası yardımla değil, afet öncesi hazırlık evresinde oluşturulması gereken bir finans sistemi ile mümkün olacaktır. Bu durumun sürdürülmesinin çok zor olduğu müșahede edilmiș olacak ki, 27 Aralık1999 tarihinde kamu tüzel kișiliğine sahip "Doğal Afet Sigortaları Kurumu (DASK)" kurulmuştur. Bu sayede afete maruz kalan vatandaşlar bir sigorta güvencesine kavuşmuşlardır. Ancak toplumunbu güvenceye yeterince ilgi göstermediği müșahede edilmektedir.

Ülkemizde sigorta güvencesi doğal afetlerin finansmanı açısından çok daha önemli hale gelmiştir. Olası İstanbul depreminde duyulacak finansman ihtiyacl, 2001 krizinin tetikleyici unsurlarından biri olan 1999 Gölcük depreminde ihtiyaç duyulan finansman miktarından birkaç kat daha fazla olacaktır.

\section{SONUÇ}

Türkiye'de afet yönetim planı, bir afet sonrasında uygulanan ilkyardımve müdahale faaliyetleri olarak algılanmakta ve başarı daha çok buna göre değerlendirilmektedir. Afet yönetimi risk ve kriz yönetimi evrelerinde oluştuğu göz önüne alınması gerekirken, ülkemizde kriz yönetimi evresi olarak karşımıza çıkmaktadır. Daha çok pansuman tedbiri olan bu tür politikalardan vazgeçip afet yönetim planlarının afet öncesi, sırası ve sonrasınadönük olarak yeniden oluşturulması gerekmektedir.Hatta afet zararlarını en aza indirmek için afet yönetiminin ilk evresi olan risk analizinin öncelemesi afet yönetiminde başarıyı artıracaktır. Kriz yönetimi daha çok olay sonrası olduğundan anlık (konjektörel) davranış gerektirirken, risk yönetimi daha çok planlama esaslı olduğu için stratejik davranış gerektirir.

Risk yönetimi yerine kriz yönetiminin öne çıkması can ve mal kaybını artırmaktadır. Zira afetin türü, büyüklüğü, nerede ve zaman olușacağı ve nasıl etkileyeceği bilinmediğinden ve ona göre hazırlık yapılmadığından dolayı dünya ölçeğinde orta büyüklükte bir afette bile ülkemizde toplumu sarsacak düzeyde can ve mal kaybı meydana gelebilmektedir. Bu durum 1999 Gölcük ve Düzce, 2003 Bingöl, 2011 Van ve 2016 Bodrum depremlerinde net bir biçimde görülmüştür. Küresel ısınma kaynaklı sel ve firtına olaylarında da bu durumu görmek mümkündür. Örneğin 2018 yılı Kasım ayında Muğla'nın Bodrum ilçesinde iki hafta içerisinde üç defa plansız yapılaşmanın ve alt yapı eksikliğinden kaynaklı sel felaketi yaşanmış, çok sayıda işyeri ve evi su basmış, onlarca aracın sel ile sürüklenmesi sonucu milyonlarca lira maddi kayıp meydana gelmiştir. Ortaya çıkan sonuç ve elde edilen bilgiye göre bu ilçe için herhangi bir afet planın olmadığı görülmektedir. Ancak afet yaşandıktan sonra, diğer bir deyişle kriz oluştuktan sonra müdahale edilmiştir. Oysa küresel ısınmaya bağlı bu olayın olacağı belli olduğuna göre yerel yönetimler tarafından hazırlanacak bütünleșik bir afet planı ile bu kayıpların azaltılması mümkündür. Benzer durumun ülkemizin geneli için geçerli olduğuna göre bu ve benzeri afetlerin yaşanmaması için iyi bir afet planının yapılması şarttır. 
Türkiye'de Afet Yönetimi Ve İș Sağlığı Güvenliği

Afet öncesinde, ülke genelinde yerleşim alanlarına yönelik çalışmalar yapılmalıdır. Bu çalışmalar en küçük yerleşim birimini de içerecek şekilde afet haritaları, yerleşim planları, binaların yapı ve konumu, her bir binada oturan insanlara ait bilgilerin bir veri tabanına işlenerek o yerleşim birine ait veriler bir merkez toplanmalıdır. Çünkü afet sırası ve sonrasında, o yerleşim biriminde hasar gören bina ve tesislerde bulunan insanlara ait bilgiler anında yetkililer ulaştırılacak, bu bilgi arama kurtarma ekiplerine yardımcı olacaktır. Bu konuda Japonya'daki uygulamalarörnek alınabilir.

Etkili bir afet yönetiminin temelini insan unsuru oluşturmaktadır. Afet konusunda bilinçli bir toplum oluşturulamadığı takdirde, ne kadar yasal düzenleme yapılırsa yapılsın, hangi önlem alınırsa alınsın afet anı ve sonrasının yönetilmesi kolay olmayacaktır. Etkin bir afet yönetimi için;

1- İș Sağlığı ve Güvenliğinin temininde doğal ve teknolojik afetlerin olumsuz etkilerinden azaltılması içinafet planın hazırlanması gerekir. Bunun için en başta iş yerlerinde risk analiz raporu oluşturulmalıdır.

2- İSG Risk Değerlendirme Yönetmeliği'ne göre hazırlanan risk analiz raporuna göre modern ve bütünleşik bir afet yönetim planı hazırlanmalıdır.

3- Özellikle depremde ilk 72 saat arama-kurtarma açısından çok önemlidir.Hazırlanan planın gereği olarak tüm çalışan personelin ilk 72 saat eğitimi verilmeli ve tatbikat yaptırılmalıdır.

Bütünleşik afet planının ilk evresi olan risk analizi ve zarar azaltma evresi 6331 sayılı İş Sağlığı ve Güveliği Kanunu kapsamına girmektedir. İkinci evre olan kriz yönetimi Afet ve Acil Durum Müdahale Yönetmeliği ile düzenlenmektedir. Bu iki düzenleme bütünleşik afet yönetimin tüm evrelerini kapsamaktadır. İş sağlı̆̆ı ve güvenliğinin sağlanması iyi bir afet yönetim planın uygulanmasıyla gerçekleşir.

\section{KAYNAKLAR}

AFAD, (2018). Türkiye Tehlike Haritası, İçişleri Bakanlı̆̆ı, Afet ve Acil Durum Yönetimi Başkanlığı, Ankara.

AFAD, (2014), Açıklamalı Afet Yönetimi Terimleri Sözlügü̈, Başbakanlık Afet ve Acil Durum Yönetimi Başkanlığı (AFAD), Ankara

Alevcan, B.R., (1995).Radyasyonlu ortamda Yasam ve Korunma Yöntemleri, Sivil Savunma Dergisi, 37,140, 12s. Ankara.

Ayanoğlu, K., Düzyol, C., İlter, N. ve Yılmaz, C., (1996). Kamu Yatırım Projelerinin Planlanması ve Analizi, Ankara.

Balamir, M., (2002). Kentsel Risk Yönetimi: Depremlere Karşı Kent Tasarımı İçin Yöntem ve Araçlar, Doğal Afetler: Güvenlik Ị̇in Tasarlama", Derleyen E. Komut, UIA-Mimarlar Odası, 26-54.

Disaster Terminology, (2005). Prehospital and Disaster Medicine. Wisconsin: Wisconsin University.

Dönertaş, A. S., (2006). Afet Yönetimi Kapsamında Güvenli Yerleşim Yerlerinin Tasarımı İçin Kentsel Tasarım Standartlarının Geliștirilmesi”, (Mimar Sinan Üniversitesi, Fen Bilimleri Enstitüsü, Yüksek Lisans Tezi), İstanbul.

Erkoç, T.,Bardan, B., and Hamzaçebi, G., (2000). Deprem Nedir?, T.C. Bayındırlık ve İskanBakanlı̆̆ı Afet İșleri Genel Müdürlügüu, 1s. Ankara.

Ertürkmen, C.,(2006). Afet Yönetimi, Ankara Üniversitesi, Sosyal Bilimler Enstitüsü, Kamu Yönetimi ve Siyaset Anabilim Dalı, Yüksek Lisans Tezi, Ankara. 
Eren, H., (1998). Türkçe Sözlük, C.I, Ankara, Türk Dil Kurumu Yayınları, Yayın No: 549, 18s. Ankara.

Ergünay, 0., (1996). Afet Yönetimi Nedir? Nasıl Olmalıdır?,TÜBITAK Deprem SempozyumuBildiriler Kitabı, 263s. Ankara.

Ergünay, 0., (1998). Afet YönetimiEmergency Türkiye 93 First InternationalDisasterReliefandPrevetion, CivilDefence, Public Security and First AidExhibition, November 23 (27), 2s. Ankara.

Ergünay, O.,(1999). Acil Yardım Planlaması ve Afet Yönetimi, Uzman Der Dergisi, 6 (7),10s. Ankara.

Ergünay, O., (2002). Afete Hazırlık ve Afet Yönetimi. Ankara: Türkiye Kızılay Derneği Genel Müdürlüğü Afet Operasyon Merkezi (AFOM).

Ergünay, O.,(2005). Afet Yönetiminde İşbirliği ve Koordinasyonun Önemi, AfetYönetiminin Temel İlkeleri, JICA Türkiye Ofisi, 10s.Ankara.

Ergünay, 0., (2007). Türkiye'nin Afet Profili, TMMOB Afet Sempozyumu Bildiriler Kitabı, Ankara: Mattek Matbaacılık.

Erkan, A., (2010). Afet Yönetiminde Risk Azaltma ve Türkiye'de Yaşanan Sorunlar, DPT-Uzmanlık Tezleri, Sosyal Sektörler ve Koordinasyon Genel Müdürlüğü, Ankara.

Esen, K.,(2000). 17 Ağustos 1999 Marmara, 12 Kasım 1999 Düzce DepremleriIşığında Olası Benzeri Depremlerde Kullanılması Gereken Tecrübeler, Türk İdare Dergisi, 428, 31-49s.

Geray, C.,(1978). Marmara'daki Son Depremden Ders Alabilecek miyiz?,Kent Kooperatifçiliği, Türkiye Kent Kooperatifleri Merkez Birliği Süreli Yayını,109 (111), 6-7s., Ankara.

Geray, C.,(1997). Türkiye'de Yıkım (Afet) Olayları Karsısında Önlemler ve Örgütlenmeler,Amme İdaresi Dergisi. 10, 91s.

Gökçe, O., Demir, A., Özden, Ş. (2008). Türkiye'de Afet Olaylarının Mekansal ve İstatistiksel Dağılımı (Afet Envanteri 1950-2008)", 1. Doğal Afetler ve Yerbilimleri Sempozyumu, 19-22 Mart 2008, Adapazarl, ss. 121-135.

Gürer, İ., ve Yavaş, Ö.M., (1994). Anadolu'da Çı̆̆ Sorunu, Sivil Savunma Dergisi, 135, 15p. Ankara.

Kadığlu, M.,(2008). Modern, Bütünleşik Afet Yönetimin Temel İlkeleri; Kadığlu, M. ve Özdamar, E., (editörler), Afet Zararlarını Azaltmanın Temel İlkeleri; JICA Türkiye Ofisi Yayınları No: 2, 1-34s. Ankara.

Kadıoğlu, M.,(2017). Afet Yönetimi: Beklenmeyeni Beklemek, En Kötüsünü Yönetmek, Marmara Belediyeler Birliği Yayınları, İstanbul.

Keçici, M. (1994). Doğal Afetlerde Bulaşıcı Hastalıklar ve Çevre, Bayındırlık ve İskân Bakanlığı ile Belediyeler, 8, 24s. Ankara.

Koshimura, S., Hayashi, S. Gokon, H. (2014). The impact of the 2011 Tohoku earthquake tsunami disaster and implications to the reconstruction, Soils and Foundations, 54(4): 560-572

KRDAE, Boğaziçi Üniversitesi, Kandilli Rasathanesi ve Deprem Araştırma Enstitüsü, Çengelköy, İstanbul.

Macit, İ., (2016). Bütünleșik Afet Yönetiminde Boyce-Codd Form Yöntemi ile GLIDE İçerikli Veri tabanı Oluşturulması. Çukurova Üniversitesi Mühendislik Mimarlık Fakültesi Dergisi, 31 (1): 191-202.

Özmen, B. ve Özden, T., (2013). Türkiye'nin Afet Yönetim Sistemine İlişkin Eleştirel Bir Değerlendirme. İstanbul Üniversitesi Siyasal Bilgiler Fakültesi Dergisi, 49: 1-28. 
Türkiye'de Afet Yönetimi Ve İș Sağlığı Güvenliği

Şenalp, H.E.,(2000). Doğal Afetlerde Yerel Yönetimlerin Görev, Yetki, Sorumlulukve Yükümlülükleri”, İdarecinin Sesi, 14 (78), 49s.

Şengün, H., (2012) Yerel Özerklik Bağlamında Türkiye"de Değişen Afet Yönetimi Yapısı. 5. Ulusal Yerel Yönetimler Sempozyumu, Der. Ayșegül Mengi; Tayfun Çınar; Can Giray Özgül, Ankara: Sarıyıldız matbaası.

TBMM, (1999). Deprem felaketi konusunda yapılan çalışmaların tüm yönleriyle incelenerek alınması gereken tedbirlerin belirlenmesi amacıyla kurulan 10/66, 67, 68, 69, 70) Esas Numaralı Meclis Araştırması Komisyonu'nun raporu, Ankara.

Tercan, Binali, (2008) Afet Bölgelerinde Yeniden Yerleştirme ve İskân Politikaları, Doğubayazıt Afetzede Yerleşim Alanları Uygulama Örneği. Yayımlanmamış Doktora Tezi, Ankara: Ankara Üniversitesi, Sosyal Bilimler Enstitüsü.

Tercan, Binali (2011) Afet Bölgelerinde Yeniden Yerleştirme Politikaları, Planlamanın dünü, Bugünü, Yarını: Planlamada Yeni Söylem Arayışları. 2. Kentsel ve Bölgesel Araştırmalar Ağı Sempozyumu, ss. 485497. Yay. Haz. Ayda Eraydın vd., Ankara: Matsa Basımevi.

Tercan, B., (2018). Türkiye'de afet politikaları ve kentsel dönüşüm. Abant Kültürel Araştırmalar Dergisi, 3(5): 102-120.

T.C. Enerji ve Tabii Kaynaklar Bakanlığı, Enerji görünümü 2017 raporu, Ankara

TÜİK (2018), 2017 Genel Nüfus Sayımları. http://www.tuik.gov.tr/UstMenu.do?metod=temelist (Son erişim: 24 Ocak 2019)

UNISDR, 2004 “Terminology: Basic Terms of Disaster Risk Reduction", (çevrimiçi) http://www.unisdr.org/eng/library, (29.06.2008).

Uzunbıçak, L., (2005). Levent, "Yerleşim Yerlerinde Afet ve Risk Yönetimi”, (Ankara Üniversitesi, Sosyal Bilimler Enstitüsü, Kamu Yönetimi ve Siyaset Bilimi Anabilim Dalı, Kent ve Çevre Bilimleri, Doktora Tezi), Ankara.

Varol, N. ve Gültekin, T. (2016a). Afet Antropolojisi. Elektronik Sosyal Bilimler Dergisi, 15(59), 1431-1436. Doi: DOI:10.17755/esosder.89650

Varol, N. ve Gültekin, T. (2016b). Etkin Bir Göç Faktörü: Afetler, AÜDTCF, Antropoloji Dergisi, 32, 43-51.

Varol, N. ve Kaya, C. M. (2018). Afet Risk Yönetiminde Transdisipliner Yaklaşım. Afet Dergisi, 1(1), 1-8.

Wamsler, C., (2007). Managing Urban Disaster Risk Analysis and Adaptation Frameworks for Integrated Settlement Development Programming for the Urban Poor, (Lund University, Housing Development \& Management, Architecture \& Built Environment, Faculty of Engineering, PHD Thesis), Lund, Sweden.

Yavaş, H.,(2001). Doğal Afetler ve Kriz Yönetimi, Yerel Yönetim ve Denetim, 6 (2), 50s.

Yolsal, S., Taymaz, T., and Yalçıner, A.C. (2007). Understanding tsunamis, potential source regions and tsunami prone mechanisms in the eastern Mediterranean, In: the Geodynamics of the Aegean and Anatolia, The Geological Society of London, Special Publications, 291, 201-230.

Yolsal, S., Taymaz, T., and Yalçıner, A.C., (2008). Earthquake source rupture characteristic along the Hellenic arc and simulation of the AD 365 Crete earthquake and its tsunami, EGU General Assembly 2008, v. 10 .

Yılmaz, A.,(2001). Türk Kamu Yönetiminin Sorun Alanlarından Biri Olarak AfetYönetimi ve Karşılaşılan Sorunlar, Marmara Depremi Örneği, CumhuriyetÜniversitesi, Sosyal Bilimler Enstitüsü, 1-304s.Sivas. 
Afet ve Risk Dergisi Cilt: 2 Sayı: 1, 2019 (43-63)

Șakir ȘAHİN, İbrahim ÜÇGÜL Yücel, G., (2009). Depremden Fiziksel ve Sosyal Etkilenebilirlik Değerlendirme Modeli: Avcılar Orneği. Yayımlanmamış Doktora Tezi, İstanbul: Yıldız Teknik Üniversitesi Fen Bilimleri Enstitüsü. 